NASA/TM-1998-208813

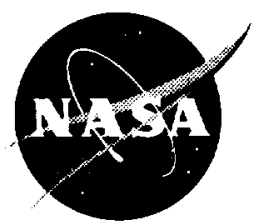

\title{
Effects of Ambient High Temperature Exposure on Alumina-Titania High Emittance Surfaces for Solar Dynamic Systems
}

Kim K. de Groh

Lewis Research Center, Cleveland, Ohio

Daniela C. Smith

Cleveland State University, Cleveland, Ohio

Donald R. Wheeler

Lewis Research Center, Cleveland, Ohio

Brian J. MacLachlan

Ohio Aerospace Institute, Cleveland, Ohio

Prepared for the Space Technology and Application International Forum sponsored by the Institute for Space and Nuclear Power Studies

Albuquerque, New Mexico, January 31-February 4, 1999

National Aeronautics and

Space Administration

Lewis Research Center 


\section{Acknowledgments}

The authors would like to thank David Roig of Cleveland State University for conducting high temperature atomic oxygen exposures and Terry McCue of Dynacs Engineering for conducting the EDS analyses.

Available from

NASA Center for Aerospace Information

7121 Standard Drive

Hanover, MD 21076

Price Code: A03
National Technical Information Service 5285 Port Royal Road Springfield, VA 22100 


\title{
Effects of Ambient High Temperature Exposure on Alumina-Titania High Emittance Surfaces for Solar Dynamic Systems
}

\author{
Kim K. de Groh ${ }^{1}$, Daniela C. Smith ${ }^{2}$, Donald R. Wheeler ${ }^{1}$, Brian J. MacLachlan ${ }^{3}$ \\ 'NASA Lewis Research Center, Cleveland, OH 44135 \\ ${ }^{2}$ Cleveland State Universit;: Cleveland. OH 44I2I \\ 'Ohio Aerospace Institute, Cleveland, OH 44142
}

\begin{abstract}
Solar dynamic (SD) space power systems require durable, high emittance surfaces on a number of critical components, such as heat receiver interior surfaces and parasitic load radiator (PLR) elements. To enhance surface characteristics, an alumina-titania coating has been applied to 500 heat receiver thermal energy containment canisters and the PLR of NASA Lewis Research Center's (LeRC) $2 \mathrm{~kW}$ SD ground test demonstrator (GTD). The alumina-titania coating was chosen because it had been found to maintain its high emittance under vacuum $\left(\leq 10^{-h}\right.$ torr $)$ at high temperatures $\left(1457^{\circ} \mathrm{F}\right.$ $\left(827^{\circ} \mathrm{C}\right)$ ) for an extended period $(\approx 2,700$ hours $)$. However, preflight verification of SD systems components, such as the PLR, require operation at ambient pressure and high temperatures. Therefore, the purpose of this research was to evaluate the durability of the alumina-titania coating at high temperature in air. Fifteen of sixteen alumina-titania coated incoloy samples were exposed to high temperatures $\left(600^{\circ} \mathrm{F}\left(316^{\circ} \mathrm{C}\right)\right.$ to $1500^{\circ} \mathrm{F}\left(816^{\circ} \mathrm{C}\right)$ ) for various durations (2 to 32 hours). Samples were characterized prior to. and after, heat treatment for reflectance, solar absorptance. room temperature emittance and emittance at $1200^{\circ} \mathrm{F}\left(649^{\circ} \mathrm{C}\right)$. Samples were also examined to detect physical defects and 10 determine surface chemistry using optical microscopy. scanning electron microscopy, operated with an energy dispersive spectroscopy (EDS) system, and x-ray photoelectron spectroscopy (XPS). Visual examination of the heat-treated samples showed a whitening of samples exposed to temperatures of $1000^{\circ} \mathrm{F}\left(538^{\circ} \mathrm{C}\right)$ and above. Correspondingly, the optical properties of these samples had degraded. A sample exposed to $1500^{\circ} \mathrm{F}\left(816^{\circ} \mathrm{C}\right)$ for 24 hours had whitened and the thermal emittance at $1200^{\circ} \mathrm{F}\left(649^{\circ} \mathrm{C}\right)$ had decreased from the non-heat treated value of 0.94 to 0.62 . The coating on this sample had become embrittled, with spalling off the substrate noticeable at several locations. Based on this research it is recommended that preflight testing of SD components with alumina-titania coatings be restricted to temperatures no greater than $6000^{\circ} \mathrm{F}$ $\left(316^{\circ} \mathrm{C}\right)$ in air to avoid optical degradation. Moreover, components with the alumina-titania coating are likely to ex perience oprical property degradation with direct atomic oxygen exposure in space.
\end{abstract}

\section{INTRODUCTION}

Solar dynamic space power systems require durable, high emittance surfaces on a number of critical components such as on the heat receiver interior surfaces and on the PLR elements. An alumina-titania coating, which has been evaluated for SD heat receiver canister applications, has been chosen for PLR (an electrical sink for excess power from the turboalternator/compressor (Shaltens, 1995)) applications due to its demonstrated high emittance and high temperature durability in vacuum (de Groh, 1994). Under high vacuum conditions $\left(\leq 10^{-6}\right.$ torr) the alumina-titania coating was found to be durable maintaining a nearly constant emittance at a temperature of $1520^{\circ} \mathrm{F}\left(827^{\circ} \mathrm{C}\right)$ for $\approx 2,700$ hours as shown in Figure I (de Groh, 1994). This coating has been successfully applied to the 500 thermal energy storage containment canisters inside the heat receiver, and the PLR radiator (Figure 2), of the $2 \mathrm{~kW}$ solar dynamic ground test demonstrator (Figure 3) at NASA LeRC. The SD GTD has successfully operated for over 500 hours in a LeRC's large thermal/vacuum space environment facility, demonstrating the feasibility of solar dynamic power generation for space applications (Shaltens, 1996a). 




FIGURE 1. Emittance versus vacuum heat treatment (at $827^{\circ} \mathrm{C}$ and $10^{-6}$ torr) time for two thicknesses of alumina-titania coating on Haynes 188 substrates.



FIGURE 2. Parasitic load radiator of NASA Lewis' SD GTD system. 
Although the alumina-titania high emittance coating has functioned successfully in the SD GTD system, SD flight PLR hardware verification will require additional ambient pressure operation. This is needed in order to verify that the electrical system and alternator control software function properly. PLR operation temperatures have been estimated to be around $1200^{\circ} \mathrm{F}\left(649^{\circ} \mathrm{C}\right)$ under full load, with a maximum design temperature of $1500^{\circ} \mathrm{F}\left(816^{\circ} \mathrm{C}\right)$. If operation of the PLR in air causes a decrease in emittance, the PLR will operate at a higher temperature than desired while on-orbit. This could shorten the PLR life, and possibly damage the system's elements. Therefore, the joint United States/Russian SD flight demonstration (SDFD) project (Wanhainen, 1995) decided to test the high temperature durability of the aluminatitania coating in air. If degradation of the high emittance surface occurs with high temperature air exposure, it is critical to determine what limitations (time/temperature) should be placed on operating the PLR in air prior to flight. It is also important to determine whether any damage could be reversed through procedures such as heat treatment in a reduction environment.

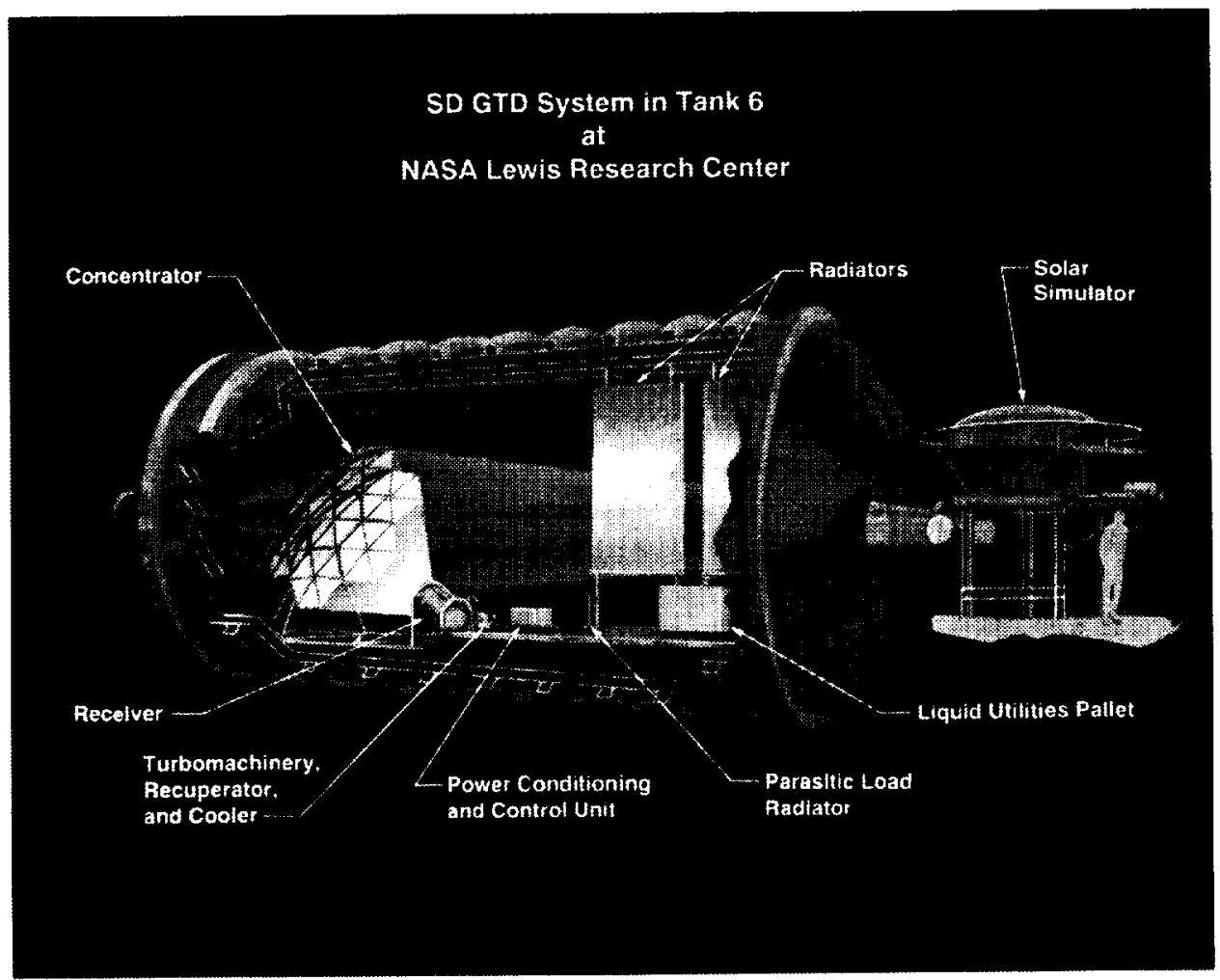

FIGURE 3. SD GTD system in the large space thermal/vacuum system at NASA Lewis Research Center.

\section{MATERIALS AND EXPERIMENTAL PROCEDURES}

AlliedSignal Aerospace, the contractor for the power conversion unit and heat receiver, prepared sixteen test coupons for durability evaluation. From an Incoloy 800 substrate. samples were cut to 1.2" x 1.2" squares and detonation gun flamesprayed at Praxair with 0.001 "-0.002" thick alumina-titania coatings. The alumina-titania composition consisted of 60 wt $\% \mathrm{Al}_{2} \mathrm{O}_{3}-40$ wt $\% \mathrm{TiO}_{2}$. Fifteen samples were heat treated in air for various durations and temperatures. Twelve samples were exposed to the array of conditions corresponding to $600^{\circ} \mathrm{F}\left(316^{\circ} \mathrm{C}\right), 1000^{\circ} \mathrm{F}\left(538^{\circ} \mathrm{C}\right)$ and $1250^{\circ} \mathrm{F}\left(677^{\circ} \mathrm{C}\right)$ for $4,8,24$ and 32 hours. Three samples were exposed to $1500^{\circ} \mathrm{F}\left(816^{\circ} \mathrm{C}\right)$ for 2,8 and 24 hours. One sample was left untreated as a control. Photographs (1.2X) and optical micrographs (12X and 101X) were taken. The samples were characterized for their optical properties (reflectance, absorptance and emittance). In addition. scanning electron micrographs. EDS spectra and XPS spectra were obtained for both the control sample and the sample exposed to the highest temperature for the longest duration (PLR15) to compare surface morphologies and chemistries. 


\section{Optical Properties}

Solar integrated total $\left(\rho_{t}\right)$, diffuse $\left(\rho_{d}\right)$, and specular reflectance $\left(\rho_{s}\right)$ were obtained using a Perkin-Elmer $\lambda-9$ Spectrophotometer operated with a $150 \mathrm{~mm}$ integrating sphere. Reflectance was measured from $250 \mathrm{~nm}$ to $2500 \mathrm{~nm}$ and the data were convoluted into the air mass zero solar spectrum to obtain solar integrated values. With opaque samples like these, the solar absorptance $\left(\alpha_{s}\right)$ can be calculated by subtracting the integrated solar total reflectance from one.

Values for emittance at room temperature $\left(\varepsilon_{77^{\circ} \mathrm{F}}\right)$ were obtained using a Gier Dunkel DB-100 infrared reflectometer which provides an integrated reflectance value which is then subtracted by $I$ to get $\varepsilon_{77^{\circ} \mathrm{F}}$. Integrated thermal emittance at $1200^{\circ} \mathrm{F}$ $\left(649^{\circ} \mathrm{C}\right)$ values were calculated using the spectral total reflectance obtained from the $\lambda$-9. Emittance was calculated by first extrapolating the last 250 data points of the total reflectance curve ( 2250 data points) to higher wavelengths to encompass $95 \%$ of the blackbody spectrum at $1200^{\circ} \mathrm{F}\left(649^{\circ} \mathrm{C}\right)$. This temperature was chosen because it was estimated to be the maximum operating temperature of the PLR on-orbit. Based on the shape of the curve for the last 250 data points from the $\lambda-9$, their root mean square (RMS) average was chosen for extrapolation. Next, the spectral absorptance was calculated by subtracting the spectral reflectance from 1. Using Kirchhoff's law $\left(\varepsilon_{\lambda}=\alpha_{\lambda}\right)$ the spectral emittance was obtained (Siegel, 1981). The spectral emittance curve was then convoluted into the blackbody curve for $1200^{\circ} \mathrm{F}\left(649^{\circ} \mathrm{C}\right)$ to give integrated thermal emittance at $1200^{\circ} \mathrm{F}\left(\varepsilon_{1200^{\circ} \mathrm{F}}\right)$. While the extrapolation introduces uncertainty in the absolute values, the data still yields valuable information by showing the overall change in emittance that was introduced due to the heat treatment.

\section{Surface Characterization}

Overall photographs were taken with a Polaroid Landcamera. Optical micrographs were taken on an Olympus SZH Stereo-zoom microscope. Electron micrographs were taken on a JEOL 840 Scanning Electron Microscope (SEM). Energy dispersive $\mathrm{x}$-ray spectrums were obtained using a Hitachi S-4700 Field Emission Electron Microscope operated at $20 \mathrm{kV}$ with an EDAX DX Prime system. X-ray photoelectron spectroscopy spectra were obtained on a VG Scientific ESCA Lab MkII using nonmonochromatized Al K-alpha $\mathrm{x}$-rays. The analyzed spot was $1 \mathrm{~mm}$ in diameter. The peak areas were converted to atomic-percent (AT\%) using sensitivity factors supplied by the manufacturer. For surface cleaning or depth profiling, the sample was sputter-etched with $2.5 \mathrm{keV}$ Ar ions rastered over a $3.5 \mathrm{~mm}$ by $3.5 \mathrm{~mm}$ area.

\section{RESULTS AND DISCUSSION}

The control and heat-treated samples are shown in Figure 4. Visual inspection of the samples indicates little degradation of the originally blue-black surfaces at $600^{\circ} \mathrm{F}\left(316^{\circ} \mathrm{C}\right)$. At higher temperatures, pronounced whitening of the surface coating is noticeable. At $1500^{\circ} \mathrm{F}\left(816^{\circ} \mathrm{C}\right)$, the coupons are essentially white and on sample PLR 15 , exposed for 24 hours at $1500^{\circ} \mathrm{F}$, embrittlement and spalling of the coating is observable (see Figure 5).

Figure 6 shows the influence of heat treatment on the reflectance of the PLR samples. Figure 7 shows the influence of heat treatment on the emittance at $1200^{\circ} \mathrm{F}$. The results indicate that treatment at $600^{\circ} \mathrm{F}\left(316^{\circ} \mathrm{C}\right)$ and $1000^{\circ} \mathrm{F}\left(538^{\circ} \mathrm{C}\right)$ did not induce a significant change in reflectance or emittance. Only after heat treatment for 8 hours at a temperature of $1250^{\circ} \mathrm{F}\left(677^{\circ} \mathrm{C}\right)$ did a significant change occur. Table 1 is a summary of the optical data obtained. This table shows that the emittance at $1200^{\circ} \mathrm{F}$ of sample PLR 15 (heated for 24 hours at $1500^{\circ} \mathrm{F}$ ) is approximately $32 \%$ lower than the emittance for the control sample. It is interesting to note that heat treatment does not affect room temperature emittance much, yet has a large effect on the high temperature emittance. This is reflected in the $\lambda-9$ spectra, where larger increases in reflectance are seen in the visible and less in the infrared wavelengths.

Electron microscopy revealed a significant change in the surface morphology of the coating with heating at $1500^{\circ} \mathrm{F}$ $\left(816^{\circ} \mathrm{C}\right)$ for 24 hours, as can been seen in Figure 8 . Between the two cases, the heat-treated sample appears to be flatter, with micro-cracks visible in the coating. The unheated coating remained electrically neutral during SEM imaging, but the heated sample became electrically charged, indicating a decrease in the electrical conductivity with heating. 


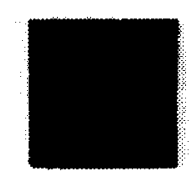

Cuntrol Linhated



$600 \%+4$ hrs
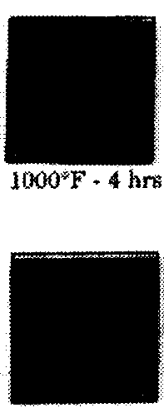

$5250^{\mathrm{m}} \mathrm{T}-4 \mathrm{hr}$

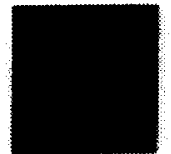

$600 \% \mathrm{~F}-8 \mathrm{hrs}$

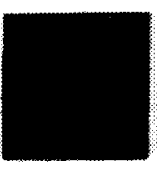

$1000^{\circ}-8 \mathrm{brs}$

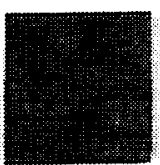

$1250 \mathrm{~F}+\mathrm{Hhra}$

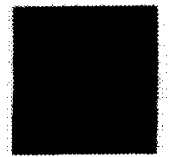

$600^{\circ} \mathrm{F}-24 \mathrm{hm}$

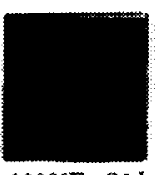

$1000^{2} \mathrm{~F}-2 \mathrm{~A}$ hrs



$1250 F^{\infty}-24$ hrs

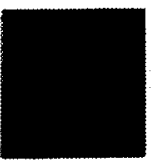

$600^{2} \mathrm{~F}-32 \mathrm{hrs}$
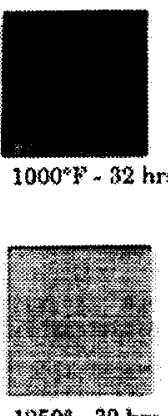

$1250^{\circ} \cdot 32 \mathrm{hm}$

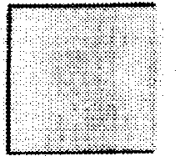

1500R - 2 br:

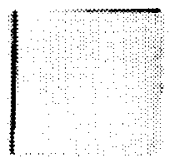

$3500 \% \cdot 5 h$

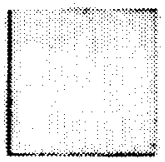

1500 f -28 has

FIGURE 4. Alumina-titania coated Incoloy samples after heat treatment at various temperatures and times in air.

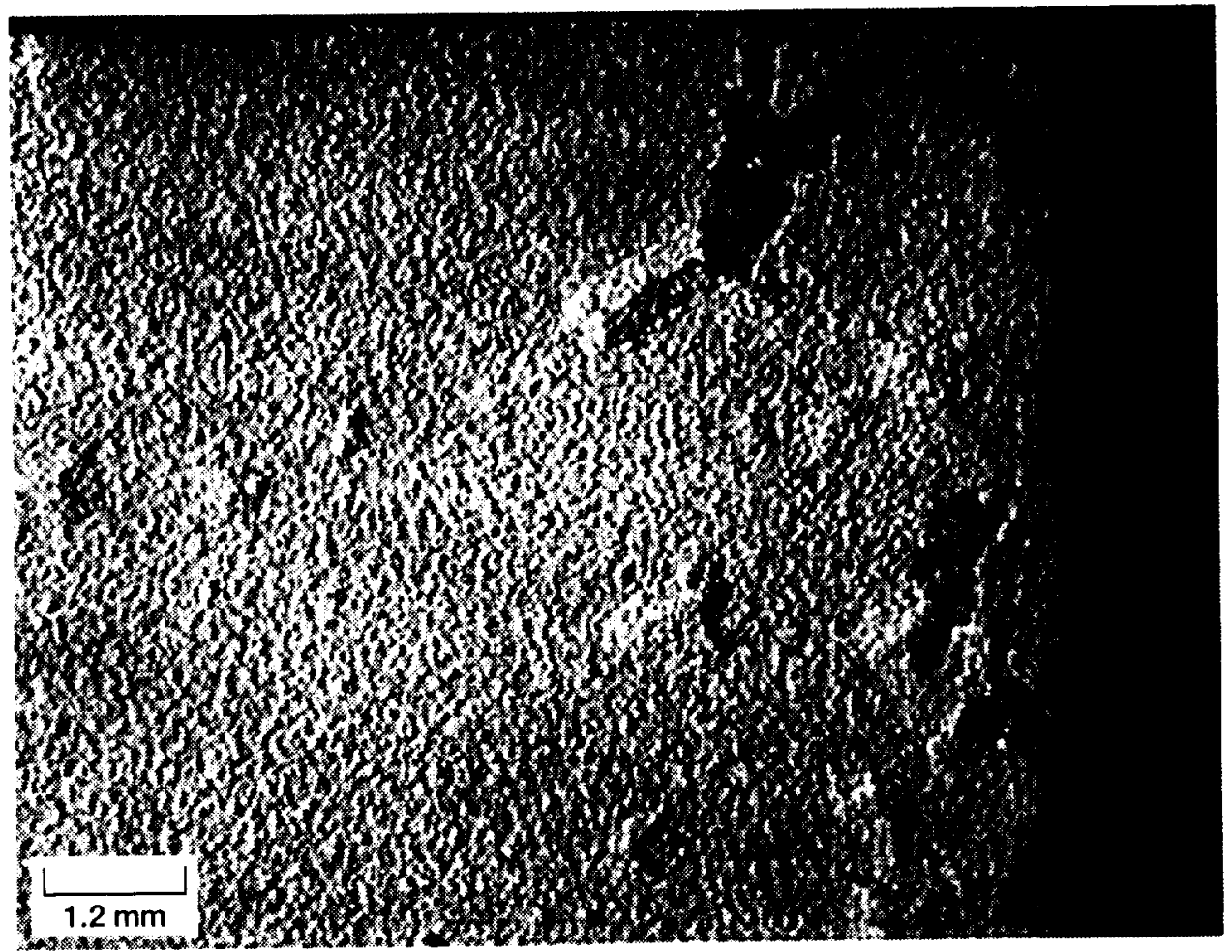

FIGURE 5. Sample PLR 15 showing coating embrittlement and spalling after heat treatment at $15000^{\circ} \mathrm{F}\left(816^{\circ} \mathrm{C}\right)$ for 24 hours. 


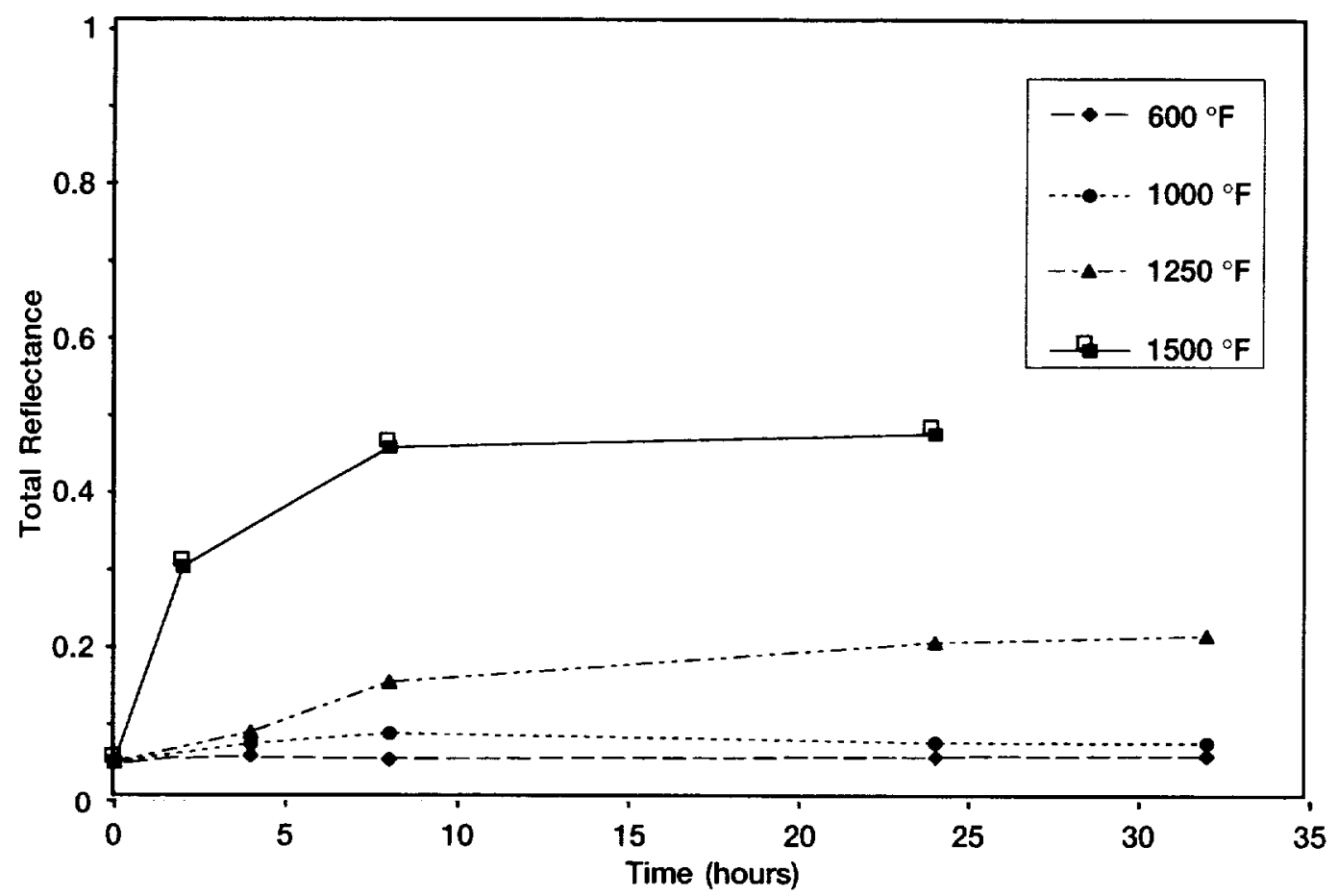

FIGURE 6. Total reflectance versus time for alumina-titania coated Incoloy samples exposed to heat treatment at various temperatures.

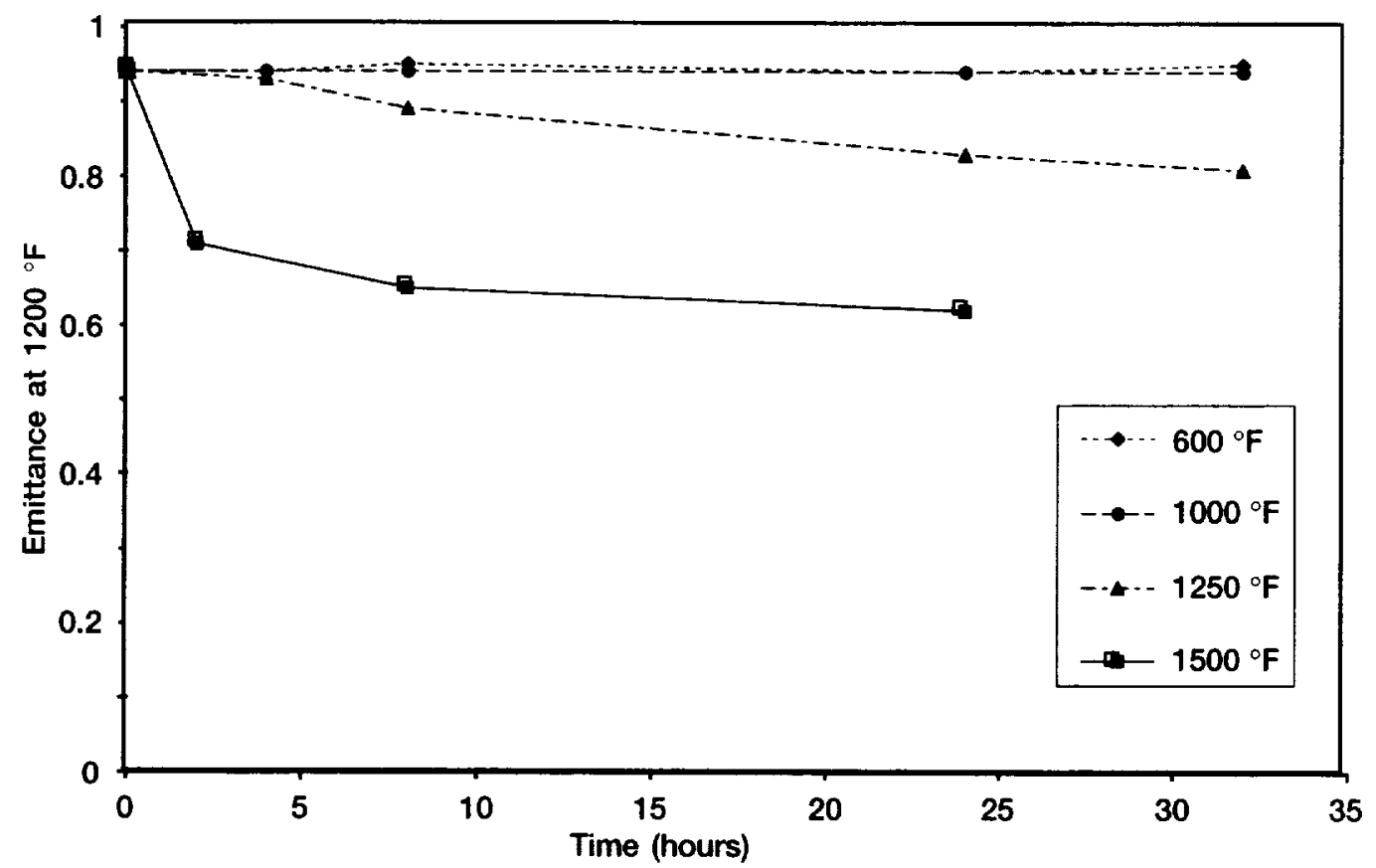

FIGURE 7. Emittance at $1200^{\circ} \mathrm{F}\left(649^{\circ} \mathrm{C}\right)$ versus time for alumina-titania coated Incoloy samples exposed to heat treatment at various temperatures. 
TABLE 1. Optical Properties of Heat Treated Samples

\begin{tabular}{|c|c|c|c|c|c|}
\hline Sample & Treatment & $\rho_{7}$ & $\alpha_{s}$ & $\varepsilon_{\pi} \mathrm{F}$ & $\varepsilon_{1200}$ \\
\hline Control & UNTREATED & 0.051 & 0.949 & 0.884 & 0.94 \\
\hline PLR 1 & $4 \mathrm{hrs}$ at $600^{\circ} \mathrm{F}$ & 0.059 & 0.941 & 0.889 & 0.94 \\
\hline PLR2 & $8 \mathrm{hrs}$ at $600^{\circ} \mathrm{F}$ & 0.054 & 0.946 & 0.88 & 0.95 \\
\hline PLR3 & $24 \mathrm{hrs}$ at $600^{\circ} \mathrm{F}$ & 0.058 & 0.942 & 0.875 & 0.94 \\
\hline PLR4 & $32 \mathrm{hrs}$ at $600^{\circ} \mathrm{F}$ & 0.059 & 0.941 & 0.883 & 0.95 \\
\hline PLR5 & $4 \mathrm{hrs}$ at $1000^{\circ} \mathrm{F}$ & 0.075 & 0.925 & 0.877 & 0.94 \\
\hline PLR6 & $8 \mathrm{hrs}$ at $1000^{\circ} \mathrm{F}$ & 0.088 & 0.912 & 0.874 & 0.94 \\
\hline PLR7 & $24 \mathrm{hrs}$ at $1000^{\circ} \mathrm{F}$ & 0.077 & 0.923 & 0.852 & 0.94 \\
\hline PLR8 & $32 \mathrm{hrs}$ at $1000^{\circ} \mathrm{F}$ & 0.076 & 0.924 & 0.86 & 0.94 \\
\hline PLR9 & $4 \mathrm{hrs}$ at $1250^{\circ} \mathrm{F}$ & 0.09 & 0.91 & 0.872 & 0.93 \\
\hline PLR10 & $8 \mathrm{hrs}$ at $1250^{\circ} \mathrm{F}$ & 0.154 & 0.846 & 0.884 & 0.89 \\
\hline PLR11 & $24 \mathrm{hrs}$ at $1250^{\circ} \mathrm{F}$ & 0.206 & 0.794 & 0.854 & 0.83 \\
\hline PLR12 & $32 \mathrm{hrs}$ at $1250^{\circ} \mathrm{F}$ & 0.215 & 0.785 & 0.86 .3 & 0.81 \\
\hline PLR13 & $2 \mathrm{hrs}$ at $1500^{\circ} \mathrm{F}$ & 0.304 & 0.696 & 0.838 & 0.71 \\
\hline PLR14 & $8 \mathrm{hrs}$ at $1500^{\circ} \mathrm{F}$ & 0.458 & 0.542 & 0.83 & 0.65 \\
\hline PLR15 & $24 \mathrm{hrs}$ at $1500^{\circ} \mathrm{F}$ & 0.476 & 0.524 & 0.84 & 0.62 \\
\hline
\end{tabular}
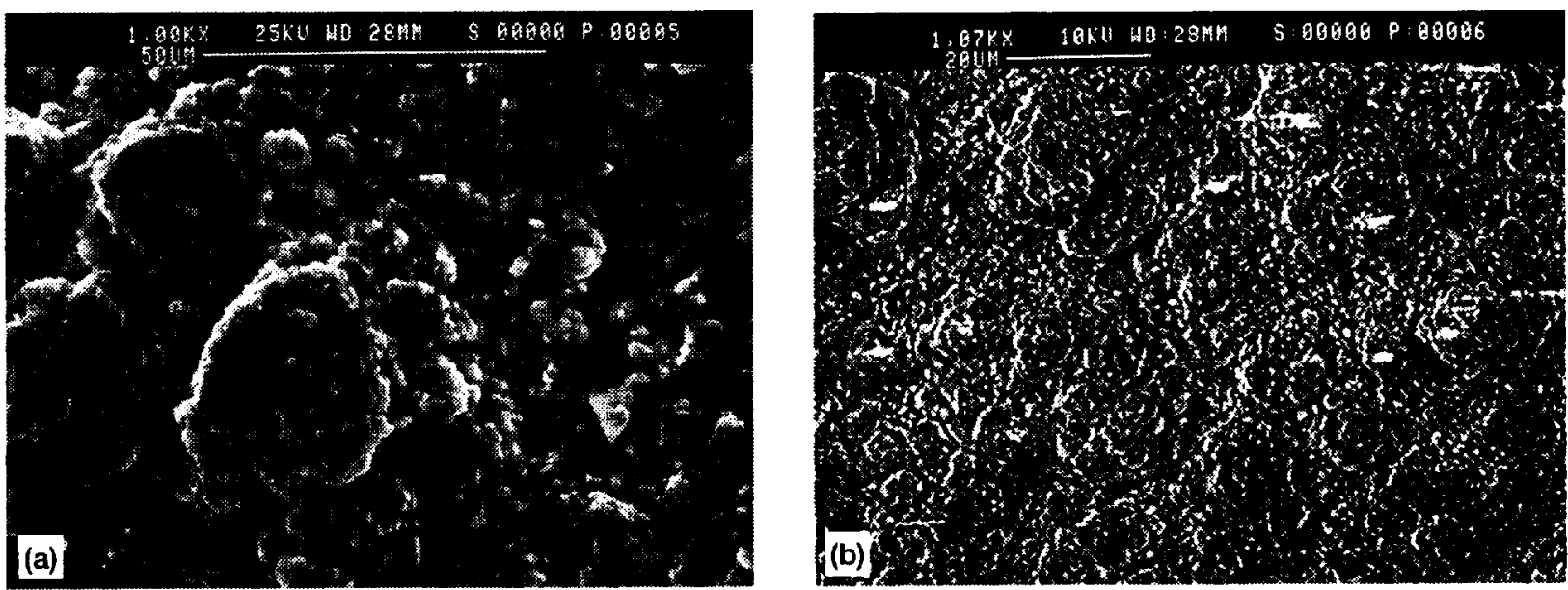

FIGURE 8. Surfaces morphologies of as-received and heat treated alumina-titania coated Incoloy samples. (a) Control sample (unheated). (b) Sample PLR 15 heated at $1500^{\circ} \mathrm{F}\left(816^{\circ} \mathrm{C}\right)$ for 24 hours.

Because the heated samples appeared flatter in the SEM, the control sample and PLR 15 were scanned for average roughness with a Dektak diamond stylus profilometer. The control sample had an average roughness of $5.6 \pm 1.2 \mu \mathrm{m}$ ( 3 scans), whereas the heated sample had an average roughness of $4.3 \pm 0.9 \mu \mathrm{m}$ ( 4 scans).

Initial XPS analyses indicated that the as-deposited coatings were very high in C (48.5 AT\% at the surface), even at sputter depths that would normally remove surface $\mathrm{C}$ ( $20.1 \mathrm{AT} \%$ at $4.3 \mathrm{~nm}$ depth). Because the coating surface is very rough. the samples were decided to be sputter etched from 4 different angles for depth profiling, in an attempt to remove surfaces that otherwise might be shielded if ion beam etching occurred from a single direction. Surface surveys and depth profiling surveys (after etching from 4 directions) of the as-received coating and a heat-treated sample are listed in Table 2 and 3 , respectively. 
TABLE 2. XPS depth profile results for the as-deposited coating

\begin{tabular}{|c|c|c|c|c|c|}
\hline \multirow{2}{*}{ Element } & \multicolumn{5}{|c|}{ As-Deposited Coating } \\
\cline { 2 - 6 } & $\begin{array}{c}\text { Peak } \\
\text { Center }(\mathbf{e V})\end{array}$ & $\begin{array}{c}\text { Surface } \\
\text { AT \% }\end{array}$ & $\begin{array}{c}\text { 1 nm depth } \\
\text { AT\% }\end{array}$ & $\begin{array}{c}\text { 43 nm depth } \\
\text { AT \% }\end{array}$ & $\begin{array}{c}\text { 147 nm depth } \\
\text { AT\% }\end{array}$ \\
\hline $\mathrm{C}$ & 285.85 & 53.730 & 60.634 & 27.470 & 12.116 \\
\hline $\mathrm{O}$ & 530.91 & 35.762 & 25.670 & 45.565 & 54.161 \\
\hline $\mathrm{Al}$ & 74.00 & 5.455 & 6.927 & 15.566 & 20.994 \\
\hline $\mathrm{Ti}$ & 458.72 & 3.111 & 3.435 & 7.758 & 9.882 \\
\hline $\mathrm{Pb}$ & 138.58 & 0.575 & 0.492 & 0.505 & 0.285 \\
\hline $\mathrm{Zn}$ & 1021.60 & 0.476 & 0.247 & 0.092 & 0.066 \\
\hline $\mathrm{Fe}$ & 712.00 & 0.204 & 1.106 & 0.914 & 1.259 \\
\hline $\mathrm{Zr}$ & 182.5 & 0.192 & 0.516 & 0.642 & 0.494 \\
\hline $\mathrm{Ca}$ & 347.14 & 0.160 & 0.349 & 0.675 & 0.474 \\
\hline $\mathrm{Cu}$ & 932.60 & 0.160 & 0.266 & 0.191 & 0.229 \\
\hline $\mathrm{K}$ & 294.85 & 0.144 & 0.208 & 0.0 & 0.0 \\
\hline $\mathrm{Ag}$ & 368.00 & 0.033 & 0.083 & 0.0 & 0.039 \\
\hline $\mathrm{W}$ & 247.56 & 0.0 & 0.065 & 0.622 & 0.0 \\
\hline
\end{tabular}

TABLE 3. XPS depth profile results for heat treated sample PLR-15

\begin{tabular}{|c|c|c|c|c|c|}
\hline \multirow{2}{*}{ Element } & \multicolumn{5}{|c|}{ Heat Treated Sample (PLR-15) } \\
\cline { 2 - 6 } & $\begin{array}{c}\text { Peak } \\
\text { Center (eV) }\end{array}$ & $\begin{array}{c}\text { Surface } \\
\text { AT \% }\end{array}$ & $\begin{array}{c}\text { 1 nm depth } \\
\text { AT\% }\end{array}$ & $\begin{array}{c}\text { 43 nm depth } \\
\text { AT \% }\end{array}$ & $\begin{array}{c}\text { 147 nm depth } \\
\text { AT\% }\end{array}$ \\
\hline $\mathrm{C}$ & 284.85 & 14.988 & 7.540 & 1.260 & 0.688 \\
\hline $\mathrm{O}$ & 530.91 & 56.863 & 60.347 & 62.889 & 62.324 \\
\hline $\mathrm{Al}$ & 74.00 & 15.188 & 17.041 & 19.986 & 21.828 \\
\hline $\mathrm{Ti}$ & 458.72 & 6.328 & 7.855 & 11.247 & 11.427 \\
\hline $\mathrm{Pb}$ & 138.58 & 0.233 & 0.472 & 0.324 & 0.098 \\
\hline $\mathrm{Zn}$ & 1021.60 & 0.027 & 0.135 & 0.084 & 0.0 \\
\hline $\mathrm{Fe}$ & 712.00 & 0.720 & 0.611 & 0.394 & 0.790 \\
\hline $\mathrm{Zr}$ & 182.5 & 0.724 & 0.659 & 0.843 & 0.768 \\
\hline $\mathrm{Ca}$ & 347.14 & 0.220 & 0.252 & 0.332 & 0.390 \\
\hline $\mathrm{Cu}$ & 932.60 & 0.110 & 0.014 & 0.004 & 0.0 \\
\hline $\mathrm{K}$ & 292.65 & 0.806 & 0.915 & 0.335 & 0.216 \\
\hline $\mathrm{Ag}$ & 368.00 & 0.666 & 0.674 & 0.271 & 0.139 \\
\hline $\mathrm{W}$ & 247.56 & 3.127 & 3.487 & 2.031 & 1.331 \\
\hline
\end{tabular}

Even after ion beam etching from 4 directions, the as-deposited coating was found to be high in C (60.3 AT \% at $1 \mathrm{~nm}$ depth). After etching to a depth of $147 \mathrm{~nm}$, there was still a substantial amount of C present in the coating (12.1 AT \%). It is possible that carbon was incorporated in the coating from the acetylene gas used during the deposition process. Small amounts of other "trace" elements such as $\mathrm{Pb}, \mathrm{Zn}, \mathrm{Fe}, \mathrm{Zr}, \mathrm{Ca}, \mathrm{Cu}, \mathrm{K}$ and $\mathrm{Ag}$ were detected. These trace elements are also likely due to the detonation gun spray process. The $\mathrm{Al}$ and Ti peak centers ( 74.00 and 458.72 , respectively) are consistent with metal oxides and not elemental metals (Moulder). At a depth of $147 \mathrm{~nm}$ there was $54 \mathrm{AT} \% 0,21.0 \mathrm{AT} \%$ Al and 9.9 AT \% Ti. It should be noted that after sputter etching to a depth of $147 \mathrm{~nm}$ where the $\mathrm{C}$ was mostly removed, the surface still appeared black.

Heating the coating in air at $1500^{\circ} \mathrm{F}$ for 24 hours resulted in a significant loss of $\mathrm{C}$ (from 53.7 to $15.0 \mathrm{AT} \%$ at the surface) and a gain in $\mathrm{O}$ (from 35.8 to $56.8 \mathrm{AT} \%$ ). The original "trace" elements changed in AT \% slightly with heat treating, and a significant amount of $\mathrm{W}$ is present in the heat-treated sample ( $3.1 \mathrm{AT} \%$ ). The binding-energy peak centers for $\mathrm{Al}$ and Ti did not change. But, a change of the Ti peak shape (two distinct peaks, one at $455.6 \mathrm{eV}$ ) was observed for the heattreated spectra at $147 \mathrm{~nm}$ depth, as compared to the as-received coating. By curve fitting for $\mathrm{TiO}_{2}$ and $\mathrm{TiO}$, the as-received coating appears to have a $\mathrm{TiO}_{2} / \mathrm{TiO}$ ratio of $\approx 1$, and the heat-treated sample has a $\mathrm{TiO}_{2} / \mathrm{TiO}$ ratio of $\approx 1.6$. It should be noted that $\mathrm{TiC}$ also has a peak at $\approx 455.0 \mathrm{eV}$ (Moulder). It has been proposed that a change in oxidation state is responsible for the optical property changes. Color changes associated with changes in the stoichiometry of alumina have been reported by Arghiropoulos. The loss of oxygen during the coating process is believed to cause the white oxides to turn 
black. At a depth of $147 \mathrm{~nm}$ the heat-treated sample has only $0.7 \mathrm{AT} \% \mathrm{C}$ compared to $62.3 \mathrm{AT} \% 0.21 .8 \mathrm{AT} \% \mathrm{Al}$ and 11.4 AT \% Ti. These quantities are closer the those expected for $\mathrm{Al}_{2} \mathrm{O}_{3}(60 \%)-\mathrm{TiO}_{2}(40 \%)$ which are 61.9 AT \% O, 28.6 $\mathrm{AT} \% \mathrm{Al}$ and $9.5 \mathrm{AT} \% \mathrm{Ti}$.

Energy dispersive spectroscopy, which is a deeper penetrating analytical technique $(1-5 \mu \mathrm{m})$ than XPS $(10-100 \AA)$, was conducted on the XPS sputter etched control sample to check if $\mathrm{C}$ was present in the bulk of the coating. The as-received coating had $10.2 \mathrm{AT} \% \mathrm{C} .54 .5 \mathrm{AT} \% \mathrm{O} .24 .9 \mathrm{AT} \% \mathrm{Al}$ and $10.4 \mathrm{AT} \%$ Ti. This is in good agreement with the XPS analysis of the as-deposited coating at a depth of $147 \mathrm{~nm}$. A SiC fiber was analyzed at the same time to verify accuracy of the system. Carbon, which is present in the as-received coating has been oxidized and is thus not present in the bulk of the heat-treated sample, and therefore may also play a minor role in the optical properties of the coating.

The emittance data suggests that ambient high temperature exposure is not a problem unless the coating is heated to temperatures above $1000^{\circ} \mathrm{F}\left(538^{\circ} \mathrm{C}\right)$. Although no significant optical property changes were observed until 8 hours of exposure at $1250^{\circ} \mathrm{F}\left(677^{\circ} \mathrm{C}\right)$, visible whitening and small changes in the reflectance and hence absorptance were observed for samples exposed $101000^{\circ} \mathrm{F}\left(538^{\circ} \mathrm{C}\right)$. This implies that the coating would not be stable at this temperature for long durations. Also, at around $1000^{\circ} \mathrm{F}\left(538^{\circ} \mathrm{C}\right)$ titania undergoes a phase change which might exacerbate oxidation and cause spalling of the coating (Leissler, private communication). This research indicates that the high temperature optical propery degradation of the alumina-titania coating is not likely reversible. The loss of $\mathrm{C}$ (which may play a minor role in optical properties) from the coating is a permanent loss. It was proposed that if the oxides do gain some oxygen during heating, exposure to a reduction environment apparently could reverse the degradation caused hy oxidation. Yet, Praxair. the coating supplier, has attempted reversal of the coating degradation using a hydrogen reduction environment but was unsuccessful (Naim, private communication). Even if it was successful, this would not reverse the embrittlement and spalling which occurred at $1500^{\circ} \mathrm{F}\left(816^{\circ} \mathrm{C}\right)$ after 24 hours. Arghiropoulos found reversible stoichiometric transformations in alumina at $932^{\circ} \mathrm{F}\left(5000^{\circ} \mathrm{C}\right)$, and irreversible transformations at $1832^{\circ} \mathrm{F}\left(1000^{\circ} \mathrm{C}\right)$.

Based on this research it is recommended that components coated with the alumina-titania coating be operated at temperatures of $600^{\circ} \mathrm{F}\left(316^{\circ} \mathrm{C}\right)$ or below in air. It is possible that there are temperatures above $600^{\circ} \mathrm{F}$ and below $1000^{\circ} \mathrm{F}$ for which the coating would be stable. However, further tests are necessary to determine a more precise failing temperature and temperatures in this range were not investigated in this test program. The SD ground test demonstrator PLR which is coated with the alumina-titania coating, has been operated for over 365 hours in air (Shaltens, 1996b). Even at the maximum load $(2 \mathrm{~kW}$ ) the heat generated by the PLR appears to be moderate (personnel could put their hands near it during operation (Shaltens, privale communication), and there has been no observable degradation of the coating. This indicates that PLR operation temperatures might be lower than estimated and thus would not pose a threat to the optical properties of the coating if operated in air.

Finally, it should be noted that based on this research, atomic oxygen (which is more reactive than molecular oxygen) degradation is likely to be a concern for operation on orbit because the PLR panels will be directly exposed to the low Earth orbit environment, unlike the heat receiver interior. The atomic oxygen durability of the coating therefore needs to be assessed prior to use of this coating on surfaces exposed to atomic oxygen impingement. Preliminary data obtained on alumina-titania coated Haynes 188 substrates provided evidence of a significant decrease in optical properties with high temperature $\left(1520^{\circ} \mathrm{F}\left(827^{\circ} \mathrm{C}\right)\right)$ atomic oxygen exposure, as shown in Figure 9. The total plasma asher exposure ( 160 hours) was equal to a Kapton effective fluence of $5.8 \times 10^{20}$ atoms $/ \mathrm{cm}^{2}$ (or a performance requirement of 0.2 years of sweeping ram atomic oxygen exposure on the International Space Station). Testing has not been conducted to sec if lower temperature atomic oxygen exposure would also cause optical property degradation.

\section{SUMMARY AND CONCLUSIONS}

Solar dynamic power system components, such as the parasitic load radiator, which are covered with a high temperature. vacuum durable, high emittance alumina-titania coating need ambient pressure operation in order to verify proper system electrical function and to check out alternator control software of actual flight hardware. Sixteen samples of aluminatitania coated Incoloy were prepared for durability evaluation at high temperature in air. Fifteen samples were heat treated at various temperatures for different durations. Visual examination of the samples indicated a whitening of the originally blue-black coating upon exposure to $1000^{\circ} \mathrm{F}$ and higher. Degradation of the optical properties of the samples exposed 




FIGURE 9. Optical property degradation of atomic oxygen exposed alumina-titania coated Haynes 188 samples at elevated temperature.

to $1000^{\circ} \mathrm{F}$ or higher was verified through reflectance, absorptance and emittance changes. A sample exposed to $1500^{\circ} \mathrm{F}$ for 24 hours appeared white, the thermal emittance at $1200^{\circ} \mathrm{F}$ decreased from 0.94 to 0.62 , and the coating became embrittled with spalling from the substrate observable in several locations. Based on this research it is recommended that components with the alumina-titania coating be operated at temperatures of $600^{\circ} \mathrm{F}\left(316^{\circ} \mathrm{C}\right)$ or below in air prior to space flight. Finally, the atomic oxygen durability of the coating appears to be a significant concern and needs to be addressed prior to use of this coating on components directly exposed to the space environment.

\section{REFERENCES}

Arghiropoulos, B.. et al., "Reactivity of Non-Stoichiometric Black Alumina." Proceedings of the 4th International Symposium on the Reactivity of Solids, Amsterdam. May 30-June 4. 1960. p. 524-539.

de Groh. K. K., Roig. D. M., Burke, C. A. and Shah. D. R., "Performance and Durability of High Emittance Heat Receiver Surfaces for Solar Dynamic Power Systems. NASA TM-106549, 1994.

Leissler, G., (NYMA. Inc.) Private Communication.

Moulder, J. F., et. al., Handbook of X-Ray Photoelectron Spectroscopy. Perkin-Elmer Corp., USA.

Naim. M. (Praxair). Private Communication.

Shaltens, R. K. \& Boyle. R. V., "Initial Results from the Solar Dynamic (SD) Ground Test Demonstration (GTD) Project at NASA Lewis," 30 ${ }^{\text {th }}$ IECEC. Orlando Florida. July 31-August 4. 1995. IECEC-95-421. also NASA TM-107004.

Shaltens, R. K. and Mason. L. S., "500 Hours of Operational Experience from a Solar Dynamic Power System." $31^{\text {st }}$ Intersociety Energy Conversion Engineering Conference. Washington, D.C., August 1 1-16, 1996a, IECEC-96568; also NASA TM-107294.

Shaltens. R. K.. and L. S. Mason. "Early Results From Solar Dynamic Space Power System Testing." NASA TM-107252, 19966. Shaltens, R. K., (NASA Lewis Research Center) Private Communication.

Siegel. R. and Howell J. R., Thermal Radiation Heat Transfer, Hemisphere Publishing Corporation. Washington. 2nd ed., 1981. Wanhainen, J. S. and Tyburski. T. E., "Joint US/Russian Solar Dynamic Flight Demonstration Project Plan." IECEC Paper No. AP-176. ASME, 1995. pp. 417-420 

Public reporting burden for this collection of information is estimated to average $t$ hour per response, including the time for reviewing instructions, searching existing data sources. gathering and maintaining the data needed. and completing and reviewing the collection of information. Send comments regarding this burden estimate or any other aspect of this collection of intormation, including suggestions for reducing this burden, to Washington Headquarters Services. Directorate for Information Operations and Reports, 1215 Jefferson Davis Highway, Suite 1204. Arlington. VA 22202-4302. and to the Office of Management and Budget, Paperwork Reduction Project (0704-018B). Washington, DC 20503.

\begin{tabular}{|l|l|l}
\hline 1. AGENCY USE ONLY (Leave blank) & 2. REPORT DATE & 3. REPOAT TYPE AND DATES COVERED
\end{tabular}

\begin{tabular}{|l|l|l}
\hline & November 1998 & Technical Memorandum \\
\hline
\end{tabular}

\begin{tabular}{|l|l|l|l|}
\hline 4. TITLE AND SUBTITLE & 5. FUNDING NUMBERS
\end{tabular}

Effects of Ambient High Temperature Exposure on Alumina-Titania

High Emittance Surfaces for Solar Dynamic Systems

\section{AUTHOR(S)}

Kim K. de Groh, Daniela C. Smith, Donald R. Wheeler, and Brian J. MacLachlan

\section{PERFORMING ORGANIZATION NAME(S) AND ADDRESS(ES)}

National Aeronautics and Space Administration

Lewis Research Center

Cleveland, Ohio 441.35-3191

9. SPONSORING/MONITORING AGENCY NAME(S) AND ADDRESS(ES)

National Aeronautics and Space Administration

Washington, DC 20546-0001
WU-6.32-1A-1E

8. PERFORMING ORGANIZATION REPORT NUMBER

E-11412

\section{SUPPLEMENTARY NOTES}

Prepared for the Space Technology and Application International Forum sponsored by the Institute for Space and Nuclear Power Studies, Albuquerque, New Mexico, January 31-February 4, 1999. Kim K. de Groh and Donald R. Wheeler. NASA Lewis Research Center; Daniela C. Smith, Cleveland State University, Cleveland, Ohio 44115; Brian J. MacLachlan, Ohio Aerospace Institute, 22800 Cedar Point Road, Cleveland, Ohio 44142. Responsible person, Kim K. de Groh, organization code 5480 , (216) 433-2297.

\section{2a. DISTAIBUTIONAVAILABILITY STATEMENT}

Unclassified - Unlimited

Subject Categories: 20 and 27
Distribution: Nonstandard

This publication is available from the NASA Center for AeroSpace Information, (301) 621-0390.

13. ABSTRACT (Maximum 200 words)

Solar dynamic (SD) space power systems require durable, high emittance surfaces on a number of critical components, such as heat receiver interior surfaces and parasitic load radiator (PLR) elements. To enhance surface characteristics, an alumina-titania coating has been applied to 500 heat receiver thermal energy containment canisters and the PLR of NASA Lewis Research Center's (LeRC) $2 \mathrm{~kW}$ SD ground test demonstrator (GTD). The aluminatitania coating was chosen because it had heen found to maintain its high emittance under vacuum $\left(\leq 10^{-6}\right.$ torr) at high temperatures $\left(1457^{\circ} \mathrm{F}\left(827^{\circ} \mathrm{C}\right)\right)$ for an extended period $(\approx 2,700$ hours). However, preflight verification of SD systems components, such as the PLR. require operation at ambient pressure and high temperatures. Therefore, the purpose of this research was to evaluate the durability of the alumina-titania coating at high temperature in air. Fifteen of sixteen alumina-titania coated Incoloy samples were exposed to high temperatures $\left(600^{\circ} \mathrm{F}\left(316^{\circ} \mathrm{C}\right)\right.$ to $\left.1500^{\circ} \mathrm{F}\left(816^{\circ} \mathrm{C}\right)\right)$ for various durations ( 2 to 32 hours). Samples were characterized prior to, and after, heat treatment for reflectance, solar absorptance, room temperature emittance and emittance at $1200^{\circ} \mathrm{F}\left(649^{\circ} \mathrm{C}\right)$. Samples were also examined to detect physical defects and to determine surface chemistry using optical microscopy. scanning electron microscopy. operated with an energy dispersive spectroscopy (EDS) system, and $\mathrm{x}$-ray photoelectron spectroscopy (XPS). Visual examination of the heal-treated samples showed a whitening of samples exposed to temperatures of $1000^{\circ} \mathrm{F}\left(538^{\circ} \mathrm{C}\right)$ and above. Correspondingly. the optical properties of these samples had degraded. A sample exposed to $1500^{\circ} \mathrm{F}\left(816^{\circ} \mathrm{C}\right)$ for 24 hours had whitened and the thermal emittance at $1200^{\circ} \mathrm{F}$ $\left(649^{\circ} \mathrm{C}\right)$ had decreased from the non-heat treated value of 0.94 to 0.62 . The coating on this sample had hecome embrittled, with spalling off the substrate noticeable at several locations. Based on this research it is recommended that preflight testing of SD components with alumina-titania coatings be restricted to temperatures no greater than $600^{\circ} \mathrm{F}\left(316^{\circ} \mathrm{C}\right)$ in air to avoid optical degradation. Moreover. components with the alumina-titania coating are likely to experience optical property degradation with direct atomic oxygen exposure in space.

\begin{tabular}{|l|l|l}
\hline 14. SUBJECT TERMS & 15. NUMBER OF PAGES
\end{tabular}

Solar dynamic system; Thermal emittance; Solar absorptance: Alumina-titania; Heat treatment; Ambient pressure; High temperature durability; Solar dynamic ground test demonstrator

\begin{tabular}{|c|c|c|}
\hline $\begin{array}{c}\text { 17. SECURITY CLASSIFICATION } \\
\text { OF REPORT } \\
\text { Unclassified }\end{array}$ & $\begin{array}{c}\text { 18. SECURITY CLASSIFICATION } \\
\text { OF THIS PAGE } \\
\text { Unclassified }\end{array}$ & $\begin{array}{c}\text { 19. SECURITY CLASSIFICATION } \\
\text { OF ABSTRACT } \\
\text { Unclassified }\end{array}$ \\
\hline
\end{tabular}

